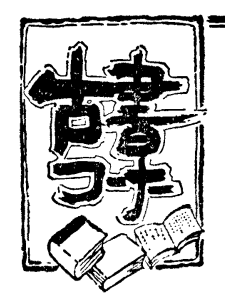

『延喜式!

起喜（901９22）は平安遷都から䄪 110 年後, 式は和 訓では「のり」と読み, てほん, かた，招きての意味で ある。

法制史上, 律命格式時代（略して律令時代）といわれ るのは広義では大化改新 (645) から平安亦期 (1190)こ ろまでの 5 世纪以上にわたる長い時期であるが，その政 治的精神が守られたのは延喜のころまでで, 以後は藤原 一网の摂関政治と变る。そして延喜去は律命封伦の最後 の法令全書となった。

平安遷都前後から乱れ始めた天皇中心の築権的国家体 制を再與しょうと, 酸醐天皇は藤源時平らに法令の整備 や集成を命じたのは延喜 5 年 (905)，そして完成は 22 年後の延長 5 年 (927) で, 実施はさらに 40 年後の康保 4 年 (967)である。こんなに悠長な経過をたどったのは 編籍者 14 名のう古藤原時亚や上級者 4 名が間もなく死亡

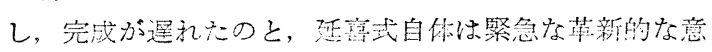

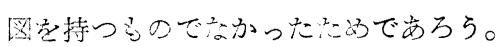

武の内容は土宝・兹老の律（教命法・刑法）之令（行

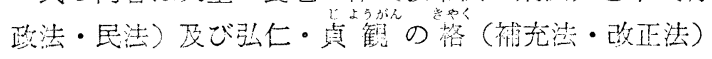
に漏れたものを補うと共化全法令の施行絽則である。全 50 巻，数干垻目に上る屁大なもので，その政治的姿勢 は民部省の項で泎玉放授や租・庸・調を規定し，これを 炽確にしている。しかし大部分は中央政府の組織とその 業務規定である。組織には, まず最高機関として神祗官 と太政宫がかり、その下に8省がある。酒と㼍は共に宮 内省の造酒司で浩られ，その数量的涀定は替40亿請しく 責かれている。汪か汇道景等については中務・宫内・层 部の各省に多少見ることができる。

\section{工原の組 織}

造酒司の役員や完員については中橪省の特服の項に次 の記事が西るだけである。

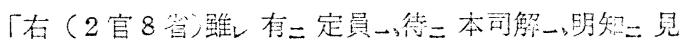
定一、然後給レ之……」

四季の倨志寺給する時は定員数によらず，所管の長の

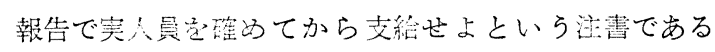

\section{式』の 酒}

$\infty$

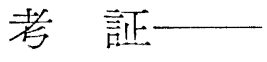

松本武一郎

が，その定筫数は延憘㕶のどこにも出ていない。これは 式は施行法であるたいで，定員数はその準损すべき律令 が別に存在していた。䍩老律令がそれである。

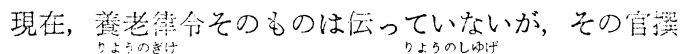

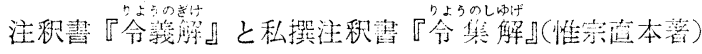

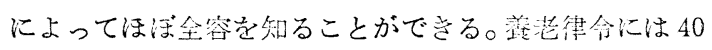

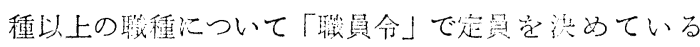
が, 造酒司は

正 1 人 祐 1 人 令贳 1 人 酒部 60 人 便部 12 人

直丁 1 人 合計 76 人

で，らち实際に酒赏造るのは渭部 60 人である。酒部は 酒造技術を持った溜户 160 户から番役として 80 人が㗨 ばれたなかの 60 人である。酒戸 160 戸は陵国 90 下, 川品国 70 戸から战り立つ。『古事記』の景行天皇の埧 には酒部は紀伊と宇伦 (倭) 注住む神櫛王（景行天皇の 第 5 王子) の子孫となっているが，この将代は紀伊と川 内が入れ替っている。

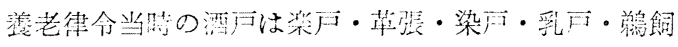
・雑工戸らとともに品部（しなべ，峦たは，ともべ)と

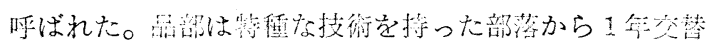

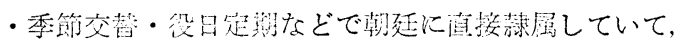

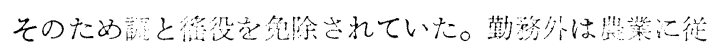

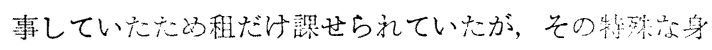

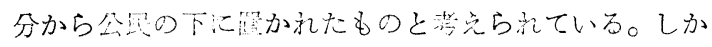

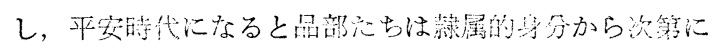

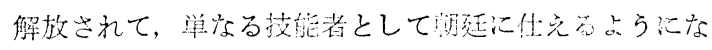
った。

\section{酒 の 酒類}

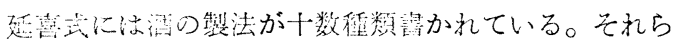
には原料配合，笠成数量が放り，酒造史上初动て思われ る具体的な文撂である。それぞ机については住江金之氏 は『酒』で，柳生倠声氏は『酒づくり談義』で，加落百 一氏は『日本の酒造りの紫み』ですで解䑫しておられ

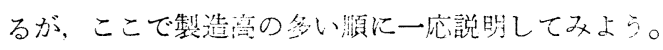

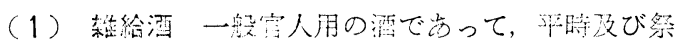

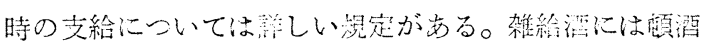
と熟酒とがある。 
頓酒一学義からすると早造りか，搾ってすぐ飲用す る酒らしい。仕迟法は 8 斗法で当時の祭集的な仕込配合 である。8斗法については後で述べる。

熟酒一十分熟成させた酒であろう。仕込法は 8 斗法 に唼べると水は 3 割多く汲み，そのため洒は 7 割 5 分增 光る。积累は米 1 石 4 斗から酒 1 石 4 斗定得ることにな

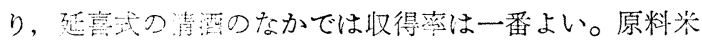

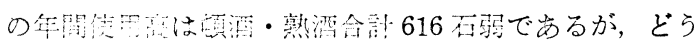
振り令けたか子からない。

（2）御酒 宮歪用や義式用の酒であろう。製造法は

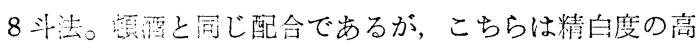

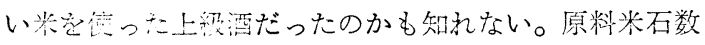
は213五で，朋つ雑給酒と合計すると 829 石となり，年 間全原齿石数 901 石の $92 \%$ に当る。

ただ、ここで注意しなければならないのは石といら単

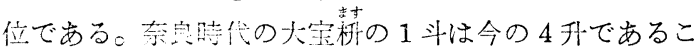
とはすでこ执べ执掠，『正税帳』の酒二本誌昭和 54 年 8 号) が，之の後地方によっては量制が崩れ，地方

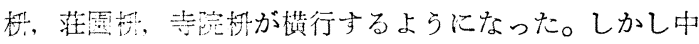
央では量肷正で宣旨枰が発们されたのは延喜より約

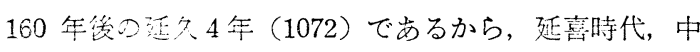
热では大至姑が正に行われていたであろら。したがっ

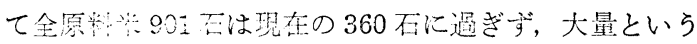
积ではない。そして，代达は1年中行なわれていたか

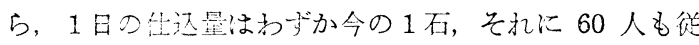
萧していたのだから，その仕事ぶりはどう想像したらよ いのだろうか。なお，宣旨析 1 斗は今の 6.25 升である。

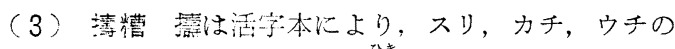

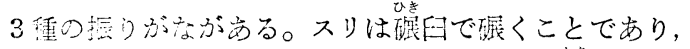

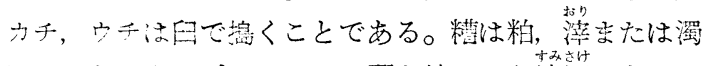
滺のことであるが，ここでは賿を搾るから清酒である。

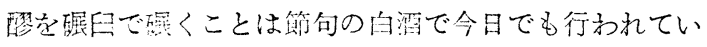

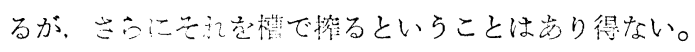

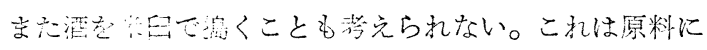

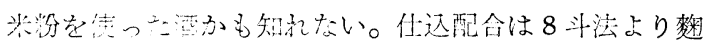

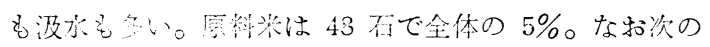

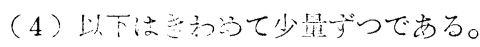

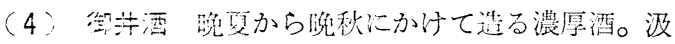

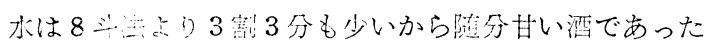

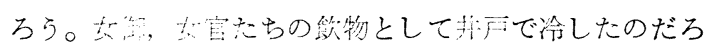
らか。

（5）醴酒・三種槽 これらの酒と次の三程糟の特街

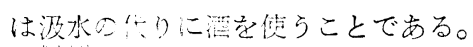

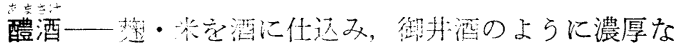
酒である。こして控らずにそのま集ら全酒類の中のた

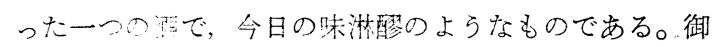

井酒に先だつ盛夏用の酒で 60 日閵，每日米 4 年・获 2 升・酒 3 升の小仕込を 1 本ずつする。

三種糟一（イ）米・䅗・小麦もやし（口)糯米・棃・ 小麦もやし (八)精梁・憗・小麦もやしをそれぞれ酒に 仕込及，搾って正月三節会の儀式に用いる。この 3 暒の

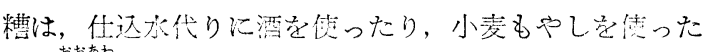

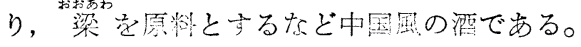

(6) 汁糟・粉酒 字からどらいら洒か判断のしょう がない。仕迟は8斗法。汁糟については 9 月から 5 月ま で每日御㢄子所（天皇の御膳を供進する所）へ4升，進 物所（宮徍の食事を調理する所）へは 2 升行くと書かれ ているから調味用の酒らしい。粉酒は何の説明もない。

（7）白貴・黑貴 新嘗祭用の酒で, 白貴 (白酒) は 醪を大節で荒濾しした酒。黑貴 (黑酒) はそれに久佐木 （臭太常山とも書く）の灰を穊い入れた酒。仕込方法 は 8 斗法よりやや濃い。灰を入れるのは何のためだろら か。柳生健吉氏は除酸のためだといら (同氏前揭書)。 をた，『万菜集』巻 19 に白酒・黒酒を詠み込んだ文室智 奴真人の歌 (4275) があり，これについて白井光太郎博 士は短歌雑誌「心の花」第 19 巻 6 号で, 湋った見解を 速べている。それを要約すると，

「黒酒の原形は八丈島などで今（大正 4 年）でも造ら れている黑粟酒であっただろら。明治 20 年, 伊豆七島 を巡回した時, 薄黑い酒に出会った。いろいる調べると 整のかびは黑花かびで, 泡盛かびと違い, 糖化とアルコ ール化の雨作周を持ったかびであった。製法は黑聚透 1 升に亦 1 升学入れ，沸き出したら蒸した精票 3 升 4 台と 水 4 升を加え, 数日して搾って倽用に倛していた。日本 本土にも古代, 米酒以前にこの種の栵酒があったが, 粟 酒の風椙は米酒に劣るので，いつのまにかすたれてしま った。しかし，その名残りに万葉時代には儀式酒として 黑栗酒を猢前に供えていただろら。あの万葉歌の作られ た天平勝宝の頃から約 200 年経った延喜時代には簡略化

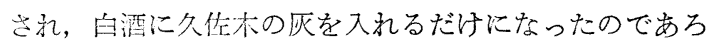
ら॰」

こら解积すると，圧は酸中和用でなく，着色用と考兄 られ，久佐木の灰は白灰でなく，黑炭にして細粉した灰 とみるべきだろう。白酒・黑酒は神前酒であり，儀式酒 であるから，これを実用的に考えず，遠い酒の歴史の色 と考える方が，いかにもロマンチックである。米酒醪の 白・黑墔酒醪の黑が本来の姿かも知れない。当否はわか らないが，白井博士の卓抜な発想には敬服する。

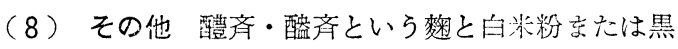

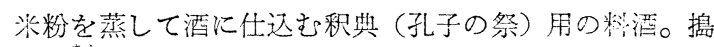

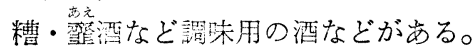

なお，山槣百治氏藷『東亚醇酵化学諭政』を見ると， 
これら酒名のなかて『詩経』、『礼記』、周礼』からの借 用があり，それらは，原典にさかのぼってもその実態は つかめない。

8 斗法 製造法の書かれた酒類の $7 \sim 8$ 割までが 8 斗 法で仕込まれる。8 斗法は清酒 8 斗を得るための仕込法 で, 次の通りである。

米 1 石橧 4 斗水 9 斗

この歩合を見ると

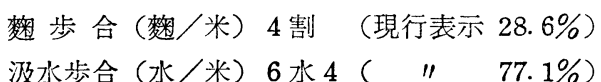

测水步合（水/

これから清酒 8 斗を得られるから

醪垂歩合 (酒/醪) 4 垂れ（"） 約 40\%)

また酒粕 1 石を 50 貫とし, 搾り欠減なしとして計算 すると酒粕総量 61 貫（容量 1 石 2 斗 2 升）となる。

粕歩合 (粕重量/米石数) 43貫 6 （" " 109\%) 清酒歩合 (酒/米) 5 割 7 分 ( " $68.6 \%$ ) 即ち米 1 石から清酒 5 斗 7 升よりできないし, 酒粕の重 量は米の重量よりも多い。これ較べ寬政時代の製法は 『日本山海名産図会』によると汲水は 5 水 2 と延喜式上 り水を詰めながら酒量は米とほ添同じ量を得ている。延 喜式の清酒収得率の極めて低いのは醪の控り方法の未発 達による。だが，他方酒粕についていえば汁気が多く， 湯にといても十分酔光るし，水を加えて打けば活発酒 醱酵したであろう。

\section{仕込操作——珀——}

原料米 畿内 (山城・大和・河内 - 和泉 - 摄津) の正 税稲と国・省営田稲から調達される。『正税帳』に載っ ていた紀伊正税酒米は延喜式にはない。紀伊の酒米と酒 部がはずされたのは首都が平城から平安へ移ったためだ ろらか。稲は春女たち 4 人が貺豰し捣精する。薪は採薪 守とその部下たちが用意する。そして薪や酒米を運ぶた め牛 1 頭を右馬寮から受けて使う。

容器 大蕉である。主計寮では毎年畿内から 1, 188 個 の萄器を調として取り立てた。小は 4 合受けの中片圷 274 個, 大は八丁池由加・瓦各 5 石受けまで十数種類あ るが, この 5 石 (今の 2 石) 受けは多分酒裂で, 毎年補 充, 支給されたのであろら。これなら醪推定量 2 石 2 升 (今の 8 斗 1 升) の 8 斗法仕込にも十分使元る。

仕込操作については各種仕込法を記した後に

「各始二醇造一、経レ旬為レ醞，並限二四度一」

とある。䣿の字に吉川弘文館本 (国史大系, 新訂增補『延 喜式』）にはクサつの傍訓(フリガナ)がある。これは䤄 を和訓ではクサ〉と読むといら注である。現在ひろく読 まれている弘文館本のこの傍訓は内閣文庫本 (閣本) か
ら取ったもので, 他の経済誰誌社本 (明治 33 年刊), 日 本古典全集本 (昭和 2 年刊) や皇学叢書本 (昭和 2 年刊) にはない。この場合傍訓のクササを採るか，それを無視 して漢字の䤄の通説的解积を採るかは古代の洒造法を掘 り起す時の分岐点となる。傍訓を採るのは柳生健吉氏 (同氏前掲書) であり，漢字を採るのは加藤百一氏（同 氏前揭書) である。その結果到着点はくい違ってくる。 柳生氏はクササについてこう書いている。

「実は国史大系 (弘文館本) の醞には「クササ」と あるが，それはクとワとの見間迲いであることを発見 するまでに，私は「クササ」の語義を求的て苦学し た。それは国史大系の校訂者の誤植によるものか，あ るいはその底本の写本の䛊謬を踏襲したものか，せん さくして見たいと思う。とにかく厄介な䤄の字であ る。」(同氏前揭畫)

つまり「クササ」は「ワササ」の間違いだといら。で は「ワササ」とは

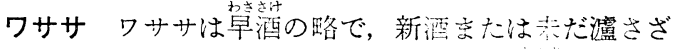
る酒，漢字では䤃と畫く(『大言海』)。また䤃汇は泡立 ったにごり酒の意味も㔖る(『学研漢和大字舆』)。柳生 氏は醠はワササであり, 早酒だと落語まで援思して堂々 の諭陣を張る。その落語では熊さんが大家さんから借り た羽織を返しに行き留守だったので概の上㯰き，金釗 流で「七」に置くと手紙に書いておいた。大家さんは筫 におくとはけしからんと怒るが,これは熊さんは「艺多 の「七」のつもりだっという笑い話で，もともと「ワサ サ」であるべきを醞の字を当てたのが間違いのもとだと いう。そして，八岐大蛇を退治した時造った八醐酒(『日 本畫紀』は早酒でなければあの緊急事態応じられな いという。その上で延喜式の前記引用文について

「その酒は打の打の造り始めて10日緗てば等㵋がで きあがり， 1 年を 4 期汇区切って造る。」(同氐前揭書) と解釈し，全部 1 段掛けであり，4期というのは酒造雑 器のなかにある「糟㕵倠一年四換」に対応するという。 4 期に分けるのは当時の清酒は長期保存がきかないので 大量の腐敗を防止するためと, 造酒雑器の雜菌污染から 守るためだといら。果してクササはワササの間違いだろ らか。

クササ さき活字本 4 種を見たが，それより古い木 版本を見る必要もあろう。木版本は正保 4 年 (1647) 以 来官命により多少訂正をしながら 7 回板行された。うち 慶安本・明暦本・享保本・文政本を調べたがいずれにる 䤄に傍訓はない。うち文政本は塙保已一が監修を手がけ た最高の本で『考異』 7 巻, 『考異附録』 3 巻, 『考異別 録』 1 总が付いていて, 造酒司には 7 つ校異がある が，本論には直接関係のない個所である。 
そらなるとワササが正しいか，クササが正しいかの判 断は大系本の宦本を調べるより他に手たてはない。この 傍訓のあるのは閣本で現在公文書館所蔵の写本である。 こんなデリケートな字になるとコピーでは判読できず, 原本を手に取る必要がある。

閣本には甲本と乙本の 2 種類がある。いずれる慶長時 代の写本と考号れており, 甲本の巻 50 の最後に延長 5 年 12 月 26 日の日付と山経書堂の奥書があり, 昌平 坂学問所の掩印がある。この日付は延喜式の完成した原 本の日付である。その後誰かがこれを書き写し朱注，朱 訓を行なったのだが，その年代や人名は判然としない。 しかしこれはどうむ乙本の二次写本のようであり, 筆 跡はやや粗雑である。そしてこの甲本の䤄の朱訓はまぎ れもなく「クサ〉」である。一方，乙本は最後の巻を欠 き奥書は見られないが，これにも朱訓がありここれは 「ク七、」となっている。「七」は左の右下の部分で平安 時代に専ら通用した漢字訓読用の片カナ，「サ」と読む から，これも「クサつ」である。「七」を使っているの を見ると甲本よりる古く，延喜式が成立して間もなく書 き込まれたものかも知れない。そして，この写本は慶長 時代よりは古いと考えられる。字体は細字で端 正であ る。

さらにクサ〉は䛊写でないと確信を持てるのは閣本乙 の頭注である。それには

「於遵久醸也酒母也」

とある。これは源をたどると久醉であり，酒母だという ことである。「久醸」こそクササなのである。ただし甲 本は「久醉」のところが「反醴」と誤写されており, 弘 文館本はこれを採り頭注に揭げているため，意味が全然 通じない。もし乙本の注を採用していたら柳生氏は迷う ことなく「クサ〉」が正しいと判断したであろらに。

久醇は成熟した酒，時には古酒のことであって（諸橋 䡴次『大灌和辞典』), 早酒と対比する。そうすると延喜 式の前記引用文は「10日もたてば醪は熟成する」と解釈 できる。続く「限二四度一」をどう解釈するか。4段仕 込であるのか， 1 年を 4 分界に分けるの意か，これだけ の字からわからない。いずれにしても正しい頭注を発見 し，クサ、が䛊写でも䛊植でもないことを知っただけで もわざわざ公文書館をたずねたかいがあった。

醞 加藤百一氏は傍訓を排して漢字の醞を採る。そし て醞を「しほる」または「しをる」と読み，上記の引用 文を次のように解く。

「造り始めて 10 日経つと醪を搾り，これを繰り返し 4 回掛けをする。そして裂期間は40日以内である。」,

「この䤄方式による酒造りが，『記紀』が編さんされ た 8 世紀初めから『延喜式』の完成をみた 10 世紀初め
までの期間に行なわれていたことは確実である。」（同 氏前掲書)

䤄の字が日本の文献上始めて出てくるのは例の八岐大 蛇退治の時の八醖酒である。この字は『日本書紀』にあ り,『古事記』の分塩折酒に対応して「しをる」と読む。 しをるはもともと繰り返し行ならことであるが，それが いつの間にか異根でよく似た絞ると重合してしまった。 こんな混乱のおこったのは『日本紀私記』の記事からで ある。

『日本紀私記』は奈良・平安両時代, 勅命により6回 『日本書紀』の長期研究会があり, その時の講師博土た らの講義やノートを集めたものである。それには八唒酒 について,

「或説, 一度醸熟, 絞= 取其汁 - ，菓二其糟—，更 用二其酒一為レ汁, 亦更醇レ 之, 如レ此八度, 是為二 純酷之酒_也」

と書かれている。この文をト部兼方は『釈日本紀日（鎌 倉時代成立）に引用した上で，この絞り説を否定し，

「是古老之説也, 而先師不レ用, 此酒二日二夜而(に

て) 熟耳 (のみ)」(弘文館『釈日本紀』)

と評し, 大蛇退治の八醖酒は二日二夜酒だという。この 発想は柳生氏の早酒説と軌を一にする。だのに今日なお 『私記』の絞り酒説の生きているのは本居宣長が『古事記 伝』の中で「此の説大かた宜しかるべし」と簡単に肯定 し結果に他ならない。

蠤の字源は藤堂明保氏編『学研漢和大字典』によると， 偏の酉は頸の細くなった雟で, 作りの膃は食物などを皿 にもり, 上からふたをかぶせた状態のこと,つまり鶽に 仕込んで気が漏れないようにふたをすることだという。 『康熙字典』(張玉書ら編) で䤄を引いてみると 15 例を

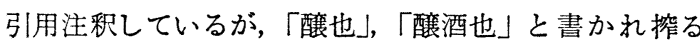
という意味はない。それが北魏時代になるとその意味は 限定されてくる。すなわち北魏時代の農業全畫『斉民要 術』（賈思妿撰＝成立は 500 年頃）に

「魏武帝に上る九䤄酒の法 憗三十斤に流水五石を 用い，䁽月二日に楝をひたす。正月凍解のころ，好い 稲米を用い，䊬涬を濾し去り，そこで仕込みをする。 三日ごとに一醸して九石米澫らると止める。常に上清 を嗜むが，涬ごめでも飲める。」（西山武一・熊代幸男 共訳)

『要汸』には42種の酒が載っているが, 酶と名の付くの はこれだけでである。この九䤄酒の特徴のなかから䤄の 宇義を探し出せるかも知れない。

九酶酒の特徴を順次拾ってみよら。

1 原料は米 北魏（後魏ともいう）は洛陽を首都之 した北支畑作地帯であるため原料は主に㯟と粟である。 
米は 42 種中 7 種に過ぎない。米を使ったのは冬米明酒

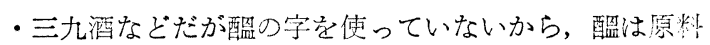
と関倸なさそうだ。

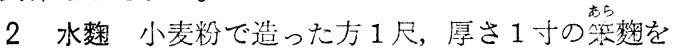

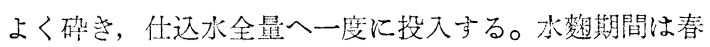

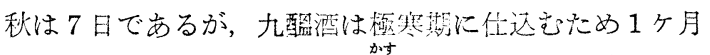

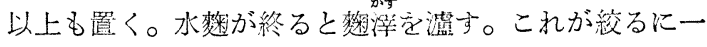
番近い操作である。しかしこの方法は他にも多数あり,

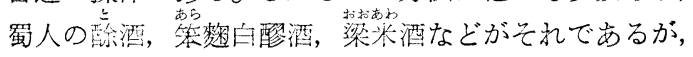
これらは皆, 䤄の字でなく酒の字を使っているから, 数 涬を瀘すことは䤄の字の本義ではなさとうだ。

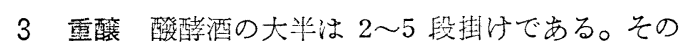
方法は全仕込水を水焚して掝いて，こ机汇等量ずつ段掛 けする方法と，1段目に全原料の半量を仕込，以後級数 的に減じていく方法とがある。九酶酒は前者である。い

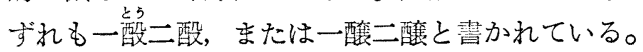

九䤄酒の最大の特徵は 9 段掛けであるが, これには濃 厚酒之高級酒という 2 つのイージがある。しかし濃度 では約 3 水の神赖頪米酒に及ばない(九䤈酒は約 5 水)か ら, 結局『斉民要術』の䤄は高級酒の意味を持つもので あろう。延喜式の䣿湾高級酒のイメージは似合わない。

漢字の「䤄」をここまで追い詰めても笽るという意味 はでてこない。

さて，『延喜式』の場合どう解釈すべきか。その前に

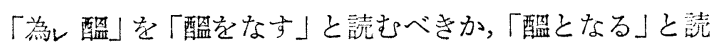
むべきか，それが重要な問題である。「醞をなす」と読 めば，単に掛けをするか，あるいは控りながら段掛け

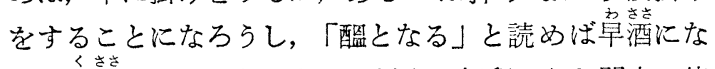

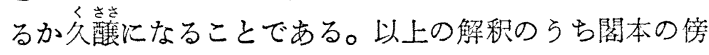
訓のクササを取り，10日たてば沸きしずをるとするのが 一番妥当ではなかららか。この一番単純な解釉, これが 私の結論である。また，段掛けであったかどらか。この 問題性橧の大きさ関係する。掛米を1回蒸し切れ なかったら当然段掛けとなる。

造酒司の造酒雑器の項には「檜三口」と書かれている が，これには大きさは書かれていない。大きさを知るた めに怡酒雑器などを調趓する民部省のうち, 交易雑器 の垻觉見なければならない。交易雑器は正税稻之交星し て入手するのであるが，それには大きさが暂かれている。

檜は字から見れば木製品である。交易傕器のうち酒造 などに関倸のある木製品は

曰 30 腰 杵 47 枚 酒檜 96 隻 槽 18 隻 円槽 15 隻 である。檜は出てこないので, 円槽がそれとより栘兄ら れない。円槽は当時まだ「たが」をはめた桶はなく韵げ 物であったろう。その底に穴をあけ, 蒸籠にしたろう。 造酒司の檜の定数は 3 口であるが, 破損伈じ 15 隻の

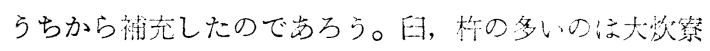
の分も含めているのだろら。

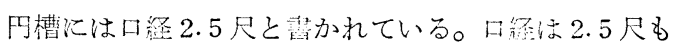

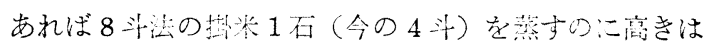

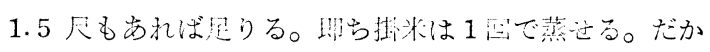

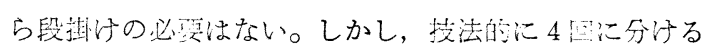
こともあり得るが，当時，そこまで考えていたかどう

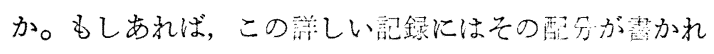
ていただろら。

\section{酒袋と酒槽}

瀘過器具として鉒・穊・酒袋・酒槽の屴ったことは前 に述べた（拙稿, 『正税帳』の酒一一本誌炤和 54 年 8 号)。そのらち主役で㘯る酒袋と酒槽について解しく見 てみよら。

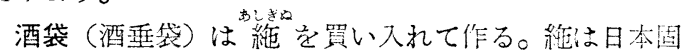
有の平織絹布で絹に較べて粗にして太く, 奈良朝以後盛 んに作られていた。酒袋は綿1反から8 条取るのである が，1 反は 2.4 尺 $\times 52$ 尺と梘定されていたから 8 枚に 切り半分に折ると大体 2.4 尺 $\times 3.25$ 尺となる。异は最 初, 梇やはかりと共に唐制にならい大宝律令で決めら

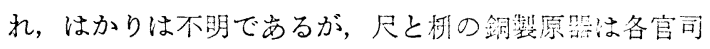
に配られていた。枓の原器は残っていないが, 尺の原嚾 は正倉院や法隆寺等に保存されており, これを今の指で 計ると0.95〜0.96 尺で今とほとんど落りはない。した がって酒袋の大きさは今でも使われているものの 2 倍位 の大きさであり，今の棑目で 7〜8 升治入れられただら う。これなら 8 斗法の 2 石醪 (今の 8 斗) も 10 枚位で 事足りたであろう。1回 60 枚。そして撗は6隻。年間 240 枚を用意し年 4 回交換した。

酒槽は毎年畿内で大小合せて96 集を正既䏦之交易し た (民部省)。大きさの内訳は

大 42 隻幅 $2.3 \sim 2.7$ 尺長さ $6 \sim 9$ 尺能 8 寸 小 11 隻幅 2.5 尺” 1 尺 " 大きさ不明 43 隻

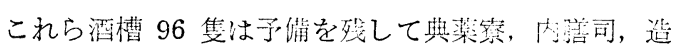
酒司など分け，破損与れば代品を請誈させた。造酒司

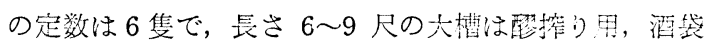
3 枚位を横に並べ, 長さ 1 尺の小槽は涬揚げ椆で 1 枚だ けを置いただろう。酒槽は大小ともに深さ8才であるか ら，3，4段㺓み重权たものと考兄られる。この㭙酒袋

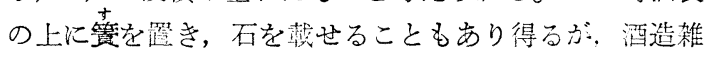

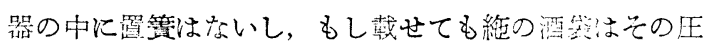
力に耐光られただろらか。控るといらよりは自然流出に 近い形であったろう。そのため醪理歩合推定 $40 \%$ とい ら数字にとどまったのだろう。 


\section{中国の古代酒と日本の古代酒}

超喜式では政治や文化は中国（唐）を範とし，それを よく消化し, 日本化しているか，酒造法に関しては中国 の影餖は想に近い。

约 1,000 年前の中国と日本の酒を敬べてみよう。

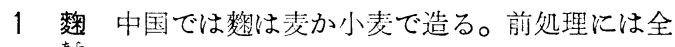

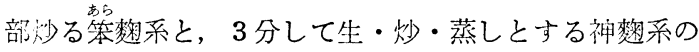
2 通りがある。いずれる製粉するのであるが，神猌の蒸 しを混合する場合はいったん干して「ほしいい」にし， 3者混合して製粉する。粉は水でこねて徚瓦状かせんべ い状にし赖むるに入れる。種柊は使わず胡菜・麦䄸・桑 菜等で覆うが，これらは野生かびの胞子を持っているた めだろらか。以後はほとんど手入れをせず，屝は土で塗 り远め 21 日蹎く(『要術』)。山崎百治氏の研究によると 繁㯰するのはリゾープス(くものすかび)やムニール(毛 かび）でアスペルギルス（急かび）は注とんどない。3

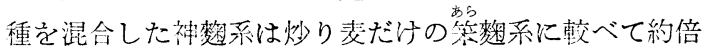

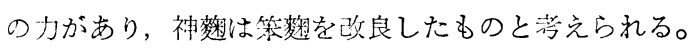
リゾープスやムコールのなかには䊰化, 醱酵の两作用を 行う種類もある(同氏『東亜酸醏化学論放』)。ほかに小

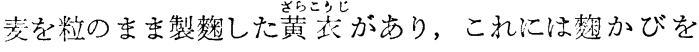
贪んだ 3 種のかびが繁殖するが(前揭㿡)，黄衣は酢や 嶈に使い, 酒造には用いない(『要術』)。

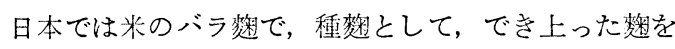
1 割まぜる(『延喜式』)。繁殖するかびは鯬かびである。 中・只の古代酒で一番相違するのは麭であるう。

2 仕込中国ではまず，仕込水全显に審全量を砝い

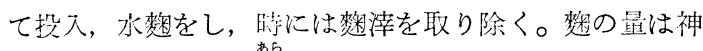

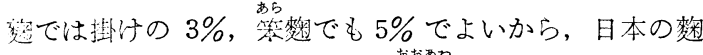

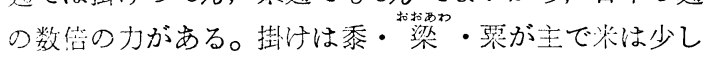

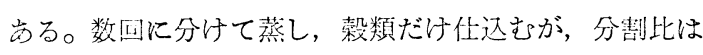
等分か，聥減方式である(『䑒術』)。

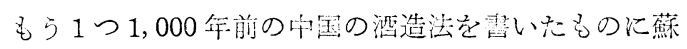
東坡の『酒経』がある(神戸税務監督局編『灘酒沿革誌』 所载)。これは『要術』と少し変っている。菼舆は 2 種類使 ら。1つは粳米粉と糯米粉と草薬で作った餅㴔。1つは 小麦と藍汁で作ったバラ猌である。掛けは米で 5 段抾け， 配分比は $6: 1: 1: 1: 1$ である。掛米を 5 斗とすると,

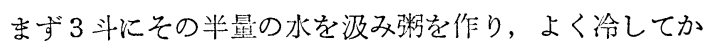
ら餅匋を砕いて投入する。3日後, 沸き出与から, さら に 3 日たって 2 次仕込。これは米 5 升を乐 2 升 5 合で粉 に炊意，冷してバラの小麦敕と共に仕込む。あと 3 回， 同じ方法を 3 日ごとにくり返すが，最後の仕込には涯水 をして汲水歩合を 9 水 5 になるよらにする。㮰は米餅 范・小麦バラ数を合せて掛けの $3.5 \%$ 。 30 日で熟成, 酒
籠で瀘して飲む。酒は草薬の香りがあり，味は辛烈であ る。特殊な酒らしいが，仕込汇は水を费わず，掛恮部 を䉼に炊くところが変っている。

さらに『要術』より約 600 年後, 延喜より約 200 年後, 『酒経』より約 100 年後の政和 7 年 (1117) に出た朱翼中 の『北山酒経』なる著書がある。これは木版本となり 『知不足斎叢書』の中に収録されており，現在は国会図 書館で見ることができるが，畫かれた技街は著しく進歩 している。即ち

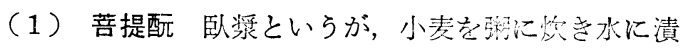
けて执き, 乳酸酸醉をして水が酸っぱくなったら濾し て, その浆を仕记水使う。

（2）暖気 追魂といらが, 配の涌き付のおそい時は 小さな瓶に熱湯を入れ，密封して䧶の底に入れて暖める。

（3）火入 火迫といらが，新酒は涬を引き，貯蔵用 㼭の口まで入れ, それ黄䗨半斤を加え, 口は油紙で密 閉する。黄蛽を入れるのは, 高温になった晆, 融けて液 面を覆い, 酒精分の蒸発を䟙ぐためだろらか。その甕を いくつか咥に入れ, 炭火を 3 ケ所で抗こし, 宝内を高温 にする。7日目沉室を開き, 冷却し, さらに 7 日後から 飲める。

いずれも, 今日の速醸酛, 暖気操作, 火入れと原理は 同じである。以上は中国である。

日本の延喜式の場合は，一回で全部仕込をすますか, 分割仕込なのか, 分割仕込なら原料配分をどうするか, 水を最初に全部汲むのか, その都度応分に汲むのか, こ れらの詳細は文字の上から読及取れない。荎提酛, 暖気, 火入れはまだない。

3 濾過 中国では上澄みを取り分㲿るか，醪をその まま饮むか(『要術』)、酒籠で瀘す(『酒経』)だけであ る。延喜より約 200 年後の『北山酒経』にやっと酒袋を 使ったらしい記事がでてくる。即ち酒槽の内側に竹筫を 立て蓝べ，袋を平になるようにして压牀（杨）で押し， 石を载せる。

日本ではすでに絁の酒袋を使っていた(『础喜式』。

要するに 1,000 年以上も前の日本の酒造法は中国とは 別に，日本で工夫されたか，南方から伝来した方法であ る。それを中国から借用した文字で表現したため，『延喜 式』の酒造法は記述の不完全さと相まって, 正確に知る ことはできない。わかったようでかからないのが、延 喜式』の酒造法である。（和歌山県酒造央編纂委員）

\footnotetext{
参考書 : 瀧川政次郎『律令の研究』(刀江書院) 村尾次郎『律令剘政史の研究』(吉川弘文餙) 虎尾俊战『超喜式』(")

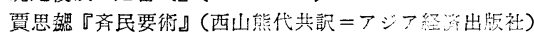

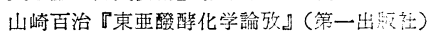
柳生健吉『酒づくり談義』(同書刊行会)

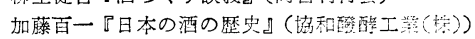

